\title{
Et forbund af celler
}

\section{Om krop, køn og identitet i ung dansk poesi}

Et sted i Amalie Smiths samling I Civil (2012) står der: "Jeg vover / at kalde det dig, // dette forbund af celler" (75). Hvor man traditionelt har henført identiteten til en metafysisk, sjælelig sfære, forankres den her på en konkret og fysisk facon. Identiteten toner frem som en specifik samling af kroppens mindste enheder, og hermed er vi inde på noget, som kendetegner dansk samtidspoesi mere generelt, nemlig et markant fokus på krop, køn og identitet. Endvidere ses der ikke kun en tendens til at gøre op med tidligere tilgange til disse emner; i den nye digtning er der også ofte et brud med klassiske forventninger til den lyriske genre. I denne artikel skal det derfor handle om, hvordan nogle af de yngste navne i dansk digtning udforsker temaer om krop, køn og identitet.

At den unge generation af forfattere - det gælder såvel lyrikere som prosaister har særlige mellemværender med disse tematikker, er allerede blevet noteret i den litterære kritik. I Information kunne man så langt tilbage som i november 2010 læse Louise Helstrup Guldagers generationsportræt af Christina Hagen, Olga Ravn, Ina Munch Christensen, Marie Kudahl og Ida Marie Hede, hvor de nye kvindelige forfatteres direkte og rå behandling af sex, begær og kropslighed blev fremhævet. ${ }^{\mathrm{I}}$ Igennem det sidste års tid har litterater og kritikere som Tue Andersen Nexø, Mikkel Krause Frantzen og Elisabeth Friis desuden bidraget til en intensivering af diskussionen om en ny forfattergeneration og dennes karakteristika. Her er Theis Ørntoft, Bjørn Rasmussen, Josefine Klougart, Asta Olivia Nordenhof og Amalie Smith også blandt de diskuterede forfattere, ligesom generationens fokus på krop og køn er blevet yderligere understreget. ${ }^{2}$

I sommeren 2012 blev det for alvor tydeligt, at de unge forfatteres værker og debatten om deres kropslige fokus er slået igennem. På bibliotekernes formidlingssite litteratursiden. $d k$ lancerede man et tema om "Kroppen i litteraturen - august 2012", hvis appetitvækker lød: "Bliv opdateret på forårets og sommerens stærkeste litterære tendens: den 'nye kropslighed' - mød den forbandede, besværlige krop, men også dens sanselige og erotiske muligheder" (Tindbæk 2012). Med en diktion 
foruroligende nær reklamebranchens sloganfyldte sprog og på grænsen til at reducere litterære værker til sæsonaktuelle modevarer blev det understreget, at kroppen er rykket i centrum for litteraturen.

Det er imidlertid ikke første gang. Også i forhold til forudgående forfattergenerationer er et kropsligt fokus blevet pointeret. Særligt markant var det i forbindelse med firserlyrikkens centrale eksponenter Søren Ulrik Thomsen, Merete Torp, Juliane Preisler og især Pia Tafdrup, hvis digte Erik Skyum-Nielsen beskrev med prædikatet kropsmodernisme. Den ældre forfattergenerations tilgang til kroppen adskiller sig dog fra de nutidige udforskninger. Man lægger ikke mindst mærke til, at de aktuelle afsøgninger er mere pågående og direkte, at de udtrykker sig i et hårdtslående sprog og på baggrund af en mere inklusiv forståelse af det poetiske.

Endvidere er det for såvel Tafdrups som Thomsens vedkommende sigende, at udviklingsprocessen i forfatterskaberne har flyttet dem længere væk fra kroppen; fra det fysiske til det metafysiske, mens tendensen nu går den modsatte vej. Det mest oplagte fællestræk mellem firserlyrikken og den nye tiergeneration er måske derfor, at de i fællesskab illustrerer, hvordan spørgsmål om krop og køn i særlig grad trænger sig på, når man er ung. Mikkel Krause Frantzen fremsætter da også det synspunkt, at det er ungdommeligheden, der skaber sammenhængskraften i den nutidige generation:

6 Det nye ved den unge 'generation' af forfattere er, at den er ung. Hold kæft en tautologi. Men det er mere end det. For første gang i lang tid er (mange af) de seneste års debutbøger lige så gamle eller rettere unge, som forfatterne selv. Der er en helt ny forbindelse og overensstemmelse mellem bøgernes sprog og forfatternes alder [...] Men de her nye forfattere skriver alle sammen om kroppen, med kroppen og som krop, og hvis man gør dét, så kan man ikke se bort fra den alder, kroppen har, og det sprog og den skrift, der strømmer ud af den selv samme krop. (Frantzen 2011)

At det samme i sin tid kunne siges om firserlyrikerne, skal jeg ikke dvæle ved her. Når man skal finde forbilleder for de aktuelle digtere, er det nemlig ikke dem, man skal vende sig mod. Retfærdigvis må man gå i flere retninger, men hvis jeg skal udpege en vej, som ligger inden for vores hjemlige breddegrader og påpeger forbindelsen til umiddelbart foregående forfattere, vil jeg fremhæve indflydelsen fra Ursula Andkjær Olsen og Mette Moestrup og som en betydningsfuld forgænger for dem Pia Juul.

\section{Formødre og mødre}

\section{- Pia Juul, Ursula Andkjær Olsen og Mette Moestrup}

Pia Juul debuterede i 1985 med samlingen levende og lukket og trådte dermed ind på den litterære scene på netop det tidspunkt, hvor det er kutyme at sige, at generationen fra de tidlige firsere takkede af. I lighed med Tafdrup er Juuls debutbog fokuseret på en piges udvikling til kvinde, ligesom det er centralt for hendes tidlige digte, at de kredser om køn, erotik og identitet. Som Peter Stein Larsen påpeger i Drømme og dialoger. To poetiske traditioner omkring 2000 (2009) er der imidlertid 
den forskel, at Juul ikke deler sin forgængers tro på, at kaos kan overkommes i en ny harmonisk tilstand, ligesom hun heller ikke formulerer sig i samme velordnede syntaktiske strukturer og organiske billedsprog. Juuls tekster har et mere sprængt udtryk, og centrallyrikkens rammer er overskredet, idet udsigelsespositionerne ofte er uklare og præget af flerstemmighed (Larsen 2009, 178).

Med Peter Stein Larsens begreb er der tale om interaktionslyrik, og det er denne interaktionslyriske norm med dens stilistiske og genremæssig heterogenitet, dens komplekse udsigelsesforhold og åbne værkbegreb, som Andkjær Olsen og Moestrup har taget til sig og videreudviklet. Desuden står de i et oplagt slægtskab med Juul, for så vidt som deres tekster vidner om et kønspolitisk engagement. Den kønspolitiske interesse kan hos begge forfattere forbindes med en feministisk diskurs, hvor der ikke alene trækkes på écriture-feminismens afsøgning af en specifik kvindelig skrift, men også ses postfeministiske tendenser til at dekonstruere den binære kønstænkning. Som en illustration af Andkjær Olsens og Moestrups behandlinger af kønnet og kroppen vil jeg fremhæve henholdsvis Have og helvede (2010) og DØ, LØGN, $D \emptyset$ (2012), eftersom disse bøger helt konkret synes at lægge spor ud, som nogle af de endnu yngre digtere forfølger.

Have og helvede er blevet til i et samarbejde mellem søstrene Ursula og Julie Andkjær Olsen, hvor Ursula har skrevet langdigtet, mens Julie har broderet, tegnet, klippet og illustreret det. Digtet består af tre spor: "Navnløs", "Slangens bog" og "Havefornemmelser" med hver deres formmæssige og billedlige udtryk, men alle med forbindelse til paradismyten, herunder krydsreferencer til forhold vedrørende godt og ondt, indenfor og udenfor, menneske og samfund, skabelse, navngivning, køn og identitet. Det er et komplekst og smukt digt, der er eksemplarisk for samtidslyrikkens eksperimenterende drive, dens genremæssige og æstetiske hybriditet. Her skal vi alene se nærmere på "Navnløs"-sporet.

Dette spor er kendetegnet ved at være opsat i kollagestil med sammenklippet maskinskrift og med brug af forskellige skrifttyper, versaler og fed. ${ }^{3}$ Først klippes der bogstav for bogstav, siden ord for ord, og afslutningsvis, hvor jeget skriver sig frem mod døden og forvandler sig til en engel, opløses skriften helt. Det tilhørende billedmateriale har ligeledes kollagens form og består primært af fotografier, illustrationer og tegninger. Materialet afbilleder mad, mineraler, planeter, primitive livsformer, væv, æg og celler, ligesom der er billeder af anonyme bygninger. Vi bevæger os fra det mikroskopiske niveau ud i verdensrummet, og der medtages såvel organisk som uorganisk stof. Yderligere er det karakteristisk, at den cirkulære form er gennemgående, hvilket endnu engang understøtter tekstens centrale tematik om skabelse og tilblivelse.

Som sin hovedhistorie synes "Navnløs" at kredse om en kvinde, der for nyligt har født. Imidlertid er teksten langt fra let at afkode, og i nogle passager kommer man i tvivl, om hun stadig er gravid, i andre om det kun er kvinden, som er udsigelsesinstans, eller om der også tales ud fra barnets perspektiv. Det er ikke altid klart, hvem 'jeg' og 'du' er i de forskellige tekststykker, og måske er hensigten netop at mime den identitetsmæssige sløring, der finder sted i situationen, hvor kvinden forvandler sig til moder, og hun og barnet befinder sig i en labil tilstand mellem at være den samme og dog forskellige. Endvidere er den nære moderskabshistorie indlejret i en 
større ramme af kulturel og samfundsmæssig karakter, hvor tematikken om skæbne og identitet spilles op mod samfundets tendens til ensretning, anonymisering og fremmedgørelse. Spørgsmålet om, hvad navnløsheden adresserer, har således flere svarmuligheder, der ikke kun forbinder sig med det lille barn, men også med kvindens identitetskrise og samfundets undertrykkelsesmekanismer.

Betragtet som en moderskabshistorie er "Navnløs" alt andet end traditionel. Tonen er aggressiv og anklagende, og følger man f.eks. det underspor, der handler om amning, ser man, at det er totalt renset for klassiske forestillinger om harmoni og idyl mellem moder og barn. Sporet kan lokaliseres fra side 12 til 24 og 43 til 45. Det indeholder udtryk som "Du er sugende for FANDEN" (12), "hjertet lede snylter" (ibid.), "den klamme parasit" (ibid.), "Jeg har hjertet siddende alle vegne. Det æder mig op indefra og du? DU suger" (ibid.), "Good Breast og Bad Breast det er dig" (18), "Sluk den lede PUMPE jeg er åben og har hjerter overalt" (19), "Good Breast og Bad Breast. Både Big Pik og Gulerod" (22), "begge brysterne og pik og gulerod" (43) og "Brystkammerat og Enemy Of The State" (45). Vreden og uforsonligheden er til at tage og føle på. Som en yderligere eksemplificering af dette træk såvel som af de komplekse udsigelsesforhold og digtets langt fra entydige form kan nedenstående strofer fremhæves:

6 S'IL VOUS PLAIT!! Hvor mange

gange skal mit

ansigt dele sig? Før jeg får et

navn. Brystkammerat og

bløde hjerne. Mit hjerte den skide

parasit. Før DU vil stille din tørst.

Stil lige din tørst jeg giver dig skæbne.

BITTE SCHÖN. Banke banke. Se jeg

kommer her med mavesækken fuld! Her

drypper fedtet FORTÆL MIG NU!

Som dette hurtige blik på "Navnløs" illustrerer, er det en poesi, hvor krop, køn og identitet står centralt. Og dét i et opbrud fra gængse konceptioner og med en kritisk udstilling af en klassisk dualistisk tænkning. "Navnløs" bryder med traditionelle kønsrolleforestillinger og giver et korrektiv til billedet af den blide, lyksalige moder. Hos Andkjær Olsen giver moderrollen ikke jeget identitet, men kaster det ud i en krise, som får afløb i en aggressivt vrængende holdning til den biologiske krops mekanismer.

Når der fokuseres på moderrollen og amningen er der naturligvis tale om en specifik kvindelig vinkel på krop, køn og identitet, og en sådan genfinder vi hos Mette Moestrup. $D \emptyset, L \emptyset G N, D \emptyset$ er dedikeret "Til mine søstre" og peger dermed i selve sin rammesætning på et kvindeligt fællesskab. Her skal vi se på bogens første del, der hedder "Hvid mælk fra det onde bryst", og som oplagt placerer sig i forlængelse af Andkjær Olsens fokus på amning og på forestillingen om henholdsvis et godt og et ondt bryst. Denne forestilling har desuden rødder tilbage til freudianeren 
Melanie Klein, som i sin beskrivelse af den maniodepressive tilstands psykogenese fremhæver det lille barns ambivalente forhold til moderens bryst, der opdeles i henholdsvis et godt, elsket bryst og et dårligt, hadet bryst, alt efter om barnet lykkes med at opnå og blive tilfredsstillet af det eller ej. Moderens bryst bliver således prototypen på gode og dårlige objekter, ligesom det faktum, at barnet har både kærlige og destruktive følelser rettet mod én og samme person, menes at danne grundlag for en dyb konflikt i dets bevidsthed (se Klein 1988).

Moestrups "Hvid mælk fra det onde bryst" handler om skam, penge, magt, udbytning, køn, sex og race - og ikke mindst om relationerne mellem disse størrelser. Igen indtager kroppen en central rolle og dét konkret som kvindekroppen, der menstruerer, har et hul eller et moderskød - alt efter hvordan man betragter det - og mælkefyldte bryster. Der spilles på stereotyper ${ }^{5}$ om kvinden som en uskyldsren Snehvide, det smukke køn, moder eller begærsobjekt, og i den såkaldte arbejdersang "Min kittel er for kort" udsættes den mandlige fantasi om sygeplejersker for ironi:

4 Min kittel er for kort, og det er noget lort, for jeg er feministisk, og kitlen er sexistisk. (51)

Ligesom i Andkjær Olsens værk er der en nær sammenhæng mellem de forskellige tekster i afsnittet, og hos Moestrup genfinder vi et spor, der handler om mælk og amning. Foruden referencen til Melanie Klein rumsterer Paul Celan og hans berømte digt "Todesfuge" i baggrunden. Celans digt indeholder et refræn om "Gryets sorte mælk" og tematiserer jødernes grufulde skæbne i de tyske koncentrationslejre. Med dette digt som resonansbund tilføjes mælkesporet derfor en dyster eksistentiel og politisk brod. Mælkesporet hos Moestrup sætter for alvor ind i "Tænkt mælk (før midnat)". Derpå udfoldes det i en gruppe tekster om mælk, der løber til brystet ved fremmede spædbørns gråd, og knyttes sammen med en hændelse, hvor en kvinde springer ud af et vindue og dør. Videre indskrives det i en historie om en gennemsigtig glasrevolver, der fyldes med hvid mælk, sort blæk og rødt blod, og som også på anden vis spiller sammen med eventyret om Snehvide, idet en ammende kvinde i opgangen kaldes ved dette navn.

I parallel til Andkjær Olsen drejer det sig om tekster, hvor nære, kropslige forhold forbindes med større sociale, kulturelle og politiske strukturer, og hvor gængse kønsrollemønstre, magtstrukturer og udbytningsforhold sættes i en kritisk belysning. I Moestrups tilfælde forbindes disse desuden til relationen mellem sorte og hvide, og det feministiske projekt tilføjes dermed en racemæssig diskurs. Er tonen kritisk, er den dog ikke aggressiv på samme måde som hos Andkjær Olsen. Snarere er der en dissimilerende ironi på færde hos Moestrup. Begge fremtræder de dog som stærke digterinder med egenartede, viltre skrivestile i opbrud fra normalsproget og traditionelle forestillinger om den lyriske genre, og som sådan synes de også at have påvirket flere af de helt unge danske forfatterinder. 


\section{Døtre - Olga Ravn og Christina Hagen}

Blandt disse er Olga Ravn og Christina Hagen, der udkom med markante digtsamlinger på Gyldendal i 2012. ${ }^{6}$ Ravns debutværk hedder Jeg æder mig selv som lyng og har undertitlen Pigesind. Der alluderes således til Tove Ditlevsens debutsamling fra 1939, og ligesom i denne bog tematiseres overgangen fra ung pige til kvinde, idet Ravn kredser omkring de skrøbelige identitetsforhold, der opstår, når man ikke kan se sig selv i de overleverede kønsrolleforestillinger. Identiteten er labil, og endnu engang er den uløseligt forbundet til kroppen og kønnet, der også her danner de centrale omdrejningspunkter i teksterne. I modsætning til Ditlevsens klassiske formsprog udtrykker Ravn sig dog på en normsprængende, eksperimenterende vis, og når man læser Jeg æder mig selv som lyng, hæfter man sig straks ved bogens formelle og sproglige radikalitet.

Uforståelighedsstrategien fra Andkjær Olsen og Moestrup får en tak opad, og det indledende afsnit med den sigende titel "Grammatisk ubehag" repræsenterer et voldsomt brud med herskende sprogregler og traditionelle forventninger til den lyriske genre. Teksterne har for lange linjer til at ligne digte, og på bogens forside genrebestemmer Ravn dem da også som poesi, hvilket kan opfattes som en mere åben kategori og dermed som et bedre match til dette ukonventionelle værk. Før man kan læse "Grammatisk ubehag", må man vende bogen på langs, men stadig modsætter teksten sig enhver form for entydig afkodning. Den første strofe lyder:

64 --- ha, et småt, et lille der stikker og stikker det lige i rød som er flere og røde døgn uden. og alene uden, med ting med blanke med rød, med berøring af blank, blank mod

hånden kolde hånd håndræk.

håndræk og ikke, alene uden, i uden og tyveriet i berøringen.

og småt blankt stikke i røde døgn og tyveriet i hånden, og brystets græmmelse, når

brystet indtræffer, bliver bryst (under hånden).

alene og uden røddøgnet unøgen utøj mig. (9)

Hakkende, gentagende skriver teksten sig frem mod et 'mig', som har den til hensigt at konkretisere, at identiteten og jeget ikke er givet på forhånd, men tværtimod er på vej til at blive til. Denne tilblivelsesproces formuleres i et sprog, der tilsidesætter gængs grammatik og syntaks, og som i en gådefuld mumlen insisterer på at finde sit eget udtryk og udfolde sig på sin specifikke vis. Sproget og identitetsdannelsen optegner med andre ord parallelle spor, og på begges vegne afvises det at indtræde $i$ allerede udstukne rammer.

På dette punkt synes det oplagt at knytte an til en lacaniansk diskurs, hvor sproget og identitetsdannelsen går hånd i hånd, og se teksten som et brud med den symbolske orden; som et tegn på ubehag ved fastsatte dikotomiske strukturer, givne rammer og regler. Eller med andre ord som et opgør med faderloven. ${ }^{7}$ Når "Grammatisk ubehag" kredser om at blive til, handler det derfor heller ikke om at blive til noget bestemt, endsige til noget fast definerbart. Til trods for Ravns distance til en klassisk symbolorienteret poesi er (rød)løget, der netop ingen kerne har, et sigende element i teksten, der peger væk fra essentialistiske identitets- og kønsopfattelser. 
Der er mange tematiseringer af kroppen og kønnet i Jeg æder mig selv som lyng, og mere specifikt fokuseres der på bl.a. brystet, huden, menstruationen, blodet og samlejet. Disse fikspunkter såvel som den gennemgående røde farve understøtter det kvindelige udgangspunkt. Man fornemmer, hvordan det lyriske jeg forsøger at undslippe bemestrende blikke, traditionelle kønsdikotomier og herre- og slaveforhold. Men man oplever også, hvordan kroppen og biologien stædigt sætter sig igennem. I det indledende afsnits sidste passage, hvor forklaring på forklaring tårner sig op i en næsten uoverskuelig mængde, hedder det:

4 fordi teksten ikke er en afsluttet orden, fordi en velopdragen logiks sære lov, fordi kvinden ikke er en sø, fordi kvinden ikke er kvinden eller ikkekvinden og fordi manden ikke er, fordi overskridelsen af kønnet i teksten ikke er nok, fordi at tilbagevinde kroppen i teksten ikke er nok, fordi kroppen findes. (15)

Tekst, køn og krop vikler sig ind i og ud af hinanden og konkretiserer dermed den komplekse relation imellem disse størrelser. Samtidig er det vigtigt at lægge mærke til, at det er kroppen, der får det sidste ord, og netop den biologiske krop danner da også udgangspunkt for bogens efterfølgende afsnit.

Det gælder i "En hvid ind i sig selv", hvor amme- og moderskabstematikken fra Andkjær Olsen og Moestrup går igen, men nu i en negeret form, idet afsnittet handler om en aborthistorie og dermed om, hvordan moderskabet afvises, fosteret suges ud. Heller ikke her indtræder jeget i den orden, hendes køn kunne menes at diktere for hende. Og ikke mindst gælder det i "Front is matter", hvor der er fokus på brystets anatomi. Igen er der tale om en revers tilgang til kroppen. Anatomisten dissekerer en død kvindes mælkefyldte bryst, hvor "mælkebanerne fletter sig som orme på brystets pude" (29). Billedet optræder på bogens forside, ligesom en gengivelse af kvindelige brystvorter i forskellige udviklingsstadier udgør bagsideillustrationen. I afsnittet forbindes historien om kirurgen og anatomisten Sir Astley Cooper, der har skrevet On the Anatomy of the Breast (1840), med det lyriske jegs egen aborthistorie, og mens hun går rundt i et museums gemakker og studerer præserverede bryster og fostre, drypper der lidt blod efter aborten ned i hendes bind. Den forbindelse, der er mellem moderskab og materialitet rent etymologisk - det latinske mater betyder både moder og stof - tages hermed meget bogstaveligt. Det er kvindens og moderskabets materialitet, der er i centrum. Til trods for undertitlens pointering af pigesindet, er værkets udgangspunkt kropslige, snarere end mentale og psykologiske, aspekter af det at være pige, kvinde og moder.

Dette kropslige eller materialistiske perspektiv er også fremhævet i titlen "Front is matter". Citat stammer fra Cooper og synes at referere til, at forsiden eller måske mere specifikt brystet er stof eller materie. Samtidig peger det dog også på det kropsliges betydningsfuldhed, og parallelt med titlen på Judith Butlers Bodies that Matter (1993) lægger Ravn op til at lege med den dobbelthed, der er indlejret i ordet matter, som på én gang henviser til stof og materialitet og til betydning. Butlers bog er desuden oplagt at inddrage, fordi hun her imødegår den kritik, der opstod i kølvandet på Gender Trouble. Feminism and the Subversion of Identity (1990), og som anklagede hende for i sin performative tilgang til køn at overse materialite- 
tens betydning. Som Unni Langås redegør for i artiklen "Kjønnets materialitet eller materialitetens kjønn? En diskussion af Judith Butlers Bodies that Matter" (2009) gør Butler sig til eksponent for et synspunkt, hvor det materielle altid allerede er diskursivt indlejret i kulturen, hvilket imidlertid ikke betyder, at materialiteten ikke tilkendes autonom status, men snarere at vi ikke har anden adgang til den end på grænsen af vores diskursivt betingede erkendelsesformer. (Langås 2009)

Jeg skal ikke udtale mig nærmere om Ravns relation til Butler, men det er klart, at Jeg æder mig selv som lyng indskriver sig i en diskussion om forholdet mellem køn og materialitet, ligesom værket til trods for fors $ø$ get på via en særsproglig praksis at slippe uden om fastsatte normer og begrænsende dikotomier uundgåeligt er udtryk for en diskursivt formidlet tilgang til køn og krop. Endvidere er Butler ikke kun relevant i en debat om $\mathrm{k} ø \mathrm{n}$ og materialitet. Hendes konstruktivistiske tilgang til køn synes også at have påvirket de måder, hvorpå køn tematiseres i den aktuelle litteratur. Det er en tilgang, hvor der gøres op med forståelsen af det kvindelige og mandlige som apriori, væsensforskellige og veldefinerede størrelser, idet det modsat fremhæves, at køn er sammensatte, fleksible former, der bliver til gennem performative praksisser.

Hvis vi optegner linjen til Andkjær Olsen og Moestrup, kan vi også her finde steder, hvor kønsforskellen udviskes. En af teksterne i "Navnløs" fra Have og helvede lyder: "Alt det DU / har givet mig med / i mavesækken: sikkerhed / og begge brysterne og pik og / gulerod. For fanden hvor / er jeg lille" (43), og i Moestrups $D \emptyset, L \emptyset G N, D \emptyset$ tales der om biseksualitet i "Bi" fra afsnittet "Meget lidt om Cleïs", ligesom afsnittet "Sort trekant" kommenterer kvindelig homoseksualitet. Hos Ravn selv undermineres forstenede kønskategorier i udtryk som "De nosser jeg har er hjertets nosser, og du tager et fast greb om min klitoris' små testikler med din tunge og dine klistrede bøvelæber" (61) samt "Jeg er på mange måder en moderne mand i mit kvinde" (ibid.). Hos samtidige mandlige poeter er den traditionelle polære kønstænkning ligeledes udfordret. Det er tilfældet i Theis Ørntofts Yeahsuiten (2009), især i "Sjollertaxa” og "Jeg går hen ad gaden”, der ender med versene:

46 jeg er en jøde, en laks, en pige med diller, mit flag er hejst, jeg har intet flag jeg bor helt omme på den ene side af jorden jeg har en etnisk baggrund jeg bor på anden sal, jeg bor på en anden sal, jeg bor på en eller anden sal jeg heiler kroppen kaster en skygge for jeget kroppen kaster en skygge for meget (34f.)

I Martin Glaz Serups Marken (2010) er der også et tekststykke, hvor marken spekulerer på, om det specifikt mandlige og kvindelige findes, og hvori dets specificitet i så fald består: "Den ved det ikke. Den må opgive det ene forsigtige forsøg på at finde ud af det, efter det andet. Alligevel føler den sig sikker på at der findes en vis essentialisme, at kønnet i dig selv medfører en forskel. Men hvordan.” (35) Selvom der er et overtal af unge kvindelige lyrikere, der tematiserer køn, kan man altså også hos de mandlige forfattere finde eksempler på, at de traditionelle binære kønsstruk- 
turer er til forhandling. Butlers skelnen mellem sex og gender, mellem biologisk og socialt køn, synes at have øvet stor indflydelse, og at den seksuelle orientering ikke tages for givet i kraft af kroppens kønstegn, ser man ligeledes i Julie Sten-Knudsens debutsamling Hjem er en retning (2011). I indledningsdigtet "Jeg" heddet det: "Jeg burde sikkert / være mere i tvivl om / min seksualitet." (9)

Opsummerende kan det nævnes, at Ravns samling understøtter den interesse for krop, køn og identitet, som vi har set hos de foregående forfattere, og dét i en æstetisk form, hvor normbruddet og kampen om og mod forståelighed er afgørende. Ligesom jeget insisterer på at udfolde sig på sin egen måde, udfolder Ravns skrift sig i et opgør med faste grammatiske regler og normer. Heller ikke på dette punkt er hun dog uden mødrende arv, og dyrkelsen af uforståelighedens æstetik rækker ikke kun tilbage til Andkjær Olsen og Moestrup. Ravns radikale sprogpraksis har en endnu ældre formoder i Gertrude Stein, som hun også selv har nævnt, at hun var optaget af i tiden omkring debutværkets tilblivelse. ${ }^{8}$ Der er mange stilistiske fællesnævnere mellem Ravn og Steins Tender Buttons (1914), der i 2004 udkom i Peter Laugesens danske oversættelse under titlen Ømme dupper. Blandt de genkomne træk er tilsidesættelsen af gængs syntaks, uvante ordkombinationer og ordophobninger, paralleliteter på såvel syntaktisk niveau som ordniveau samt fremhævelsen af ordenes stoflighed og lydlighed via allitterationer og assonanser. I overensstemmelse med det steinske diktum "The way to say it, is to say it" $\mathrm{er}$ form og indhold i Ravns poesi uløseligt forbundne, og det er som tidligere nævnt oplagt, at den labile skrift må ses i forbindelse med den labile identitet; at opgøret med den symbolske orden relaterer til et opgør med binære og repressive strukturer.

Med pointeringen af såvel en særsproglig praksis som en revolte imod herskende normer er der givet en naturlig overgang til Christina Hagens White Girl, der ligeledes fremstår som et subversivt projekt. Imidlertid kommer Hagens opgør til udtryk på en ganske anden måde, og mens Ravn primært kredser om det nære, kaster Hagen sig ud på en global og politisk betændt arena. Her forskydes fokus fra den enkeltes identitet til spørgsmålet om race og klasse, fra kvindekroppens hvide mælk til den hvide hud som racetegn og fra den enkeltes seksualitet til sex som vare i en markedssammenhæng. Hagens opgør har form af underkulturens og vrangsidens opgør. Det er et opgør med korrektheden og pænheden, og allerede et første blik på bogen afslører da også, at der ikke er tale om en hverken skønhedssøgende eller behagesyg æstetik. På bogens omslag er oplysninger om forfatter, titel, genre og forlag nedkrasset med en hurtig blyantskrift. Hagen vender sig imod de traditionelle forventninger til, hvordan en digtsamling fra Gyldendal ser ud, og i forbindelse hermed kan hendes valg af genrebetegnelse også opfattes provokativt.

Mens forsiden og titelbladet angiver, at det drejer sig om digte, står der nemlig som indgang til teksterne, at: "White Girl er en fiktionalisering af en samling postkort skrevet af hvide mennesker". Denne oplysning korresponderer med bagsideteksten og med, at der på flapomslagets indersider er trykt en masse postkort. At det bredere fiktionaliseringsbegreb er mere passende end genrebetegnelsen digte, understøttes endvidere af, at teksterne reelt fremstår som kortprosa; som kvadratiske blokke af fortløbende og handlingsorienteret tekst. Idet Hagen udvælger et kildemateriale, som hun bearbejder efter nogle bestemte regler, kan hendes værk 
yderligere kategoriseres som postproduktiv og konceptuel litteratur. Det postproduktive aspekt kommer af, at hun foretager forskydninger og manipulationer i et eksisterende tekstmateriale, mens bogens karakter af konceptkunst refererer til, at det er det samme greb, der anlægges på alle tekster. Digte, hmm. Det kan unægtelig diskuteres.

Som Peter Stein Larsen kommenterer i sin anmeldelse af White Girl i Kristelig Dagblad, er der fire stilistiske greb, der går igen. Det drejer sig om omvendt ordstilling, 'den' som bestemt artikel, fejl i substantivers køn og verber i infinitiv (Larsen 2012). Teksterne er med andre ord formuleret på såkaldt perker- eller pidgindansk. De er skrevet i et sprog, hvor afsenderen ikke bemestrer de gældende sprogregler, men tværtimod kommer til at udstille sin fremmedhed og manglende kulturelle assimilation. Hvor vi er vant til, at det er 'de andre', der udtrykker sig mangelfuldt, forskyder Hagen perspektivet, så det er den hvide piges tale, der fremmedgøres. Hvorfor nu det? Sandsynligvis fordi Hagen ønsker, at vi ikke blot vender blikket mod, hvordan de andre tager sig ud fra vores - eller mere præcist fra den hvide piges perspektiv - men også, hvordan vi selv fremstår fra deres. Der fremsættes et dobbeltblik på relationen mellem 'os' og 'dem' og lægges op til et brud med klassiske herredømmeforestillinger. Med begreber fra postkolonialismens redskabskasse kan man tale om en udsigelsesmæssig positionering in-between; om hybriditet og kreolisering.

Allerede titlen White Girl påpeger, at køns- og racetematikken står centralt. Det gjaldt også for Moestrups $D \emptyset, L \emptyset G N, D \emptyset$, og i Judith Butlers tidligere nævnte bog Bodies that Matter diskuteres forholdet mellem køn og race ligeledes. I afsnittet "Passing og queering. Nella Larsens psykoanalytiske udfordring", som er oversat til dansk i Lilian Munk Rösings og Tania Ørums antologi Feminisme (2012), finder man således en sammentænkning af race, seksualitet og kønsforskel. Med udgangspunkt i Nella Larsens roman Passing (1929) diskuterer Butler racialiseringen af seksualiteten og de forbud, der er opstillet ikke blot imod at overskride sin egen race, men også imod at efterleve et homoseksuelt begær. Butler bestrider endvidere megen feministisk tænknings hævdelse af, at kønsforskellen skulle være en mere primær forskel end andre forskelle, herunder raceforskellen. Derimod taler hun for, at kønsforskellen også altid er indlejret i en racekategori, da der ikke findes en kønstænkning, som kan sige sig uafhængig af racemæssige tilhørsforhold (Butler 2012, 75f.).

Når det synes oplagt at henvise til Butler i forbindelse med Hagen, skyldes det, at hendes bog også placerer sig i et felt, hvor forhold mellem køn og race er uløseligt forbundet. Endvidere viser det sig, at selvom spørgsmålet om seksuel orientering ikke spiller en afgørende rolle i værket, så gør det mere generelle spørgsmål om sex det ubetvivleligt. Sammen med penge fremstilles sex nemlig som en gennemgående årsag til de konflikter i de menneskelige relationer mellem kvinder og mænd, hvide og sorte, rige og fattige, som bogen udstiller. De 34 tekster tager afsæt i hvide kvinders værste rejseoplevelser og er alle centreret omkring en ubehagelig hændelse. Man følger White Girl i Athen, Harlem, Sydeuropa, Sydamerika, Tanzania, Thailand, Jamaica og mange andre steder, hvor hun er rejst ud med forventningen om at opleve noget godt, oprigtigt og spændende og har troet at skulle møde venlighed 
og forståelse. I stedet føler hun sig snydt, chikaneret, jagtet, intimideret, udnyttet, set ned på og fordømt. Et grelt eksempel, hvor penge og sex igen er i centrum, adresseres "Til mand i land generel" og lyder:

64 Alle steder jeg gå, du min penge vil ha, du min pizza vil spise (din barn mig spørge: "Må få? Må få? Må få?"), du den dårlig samvittighed mig vil gi. Men du den skid ikke gi for mig. Jeg i min seng ligge, dødssyg, jeg efter læge ringe, og den læge bare sige, han min penge vil ha. Jeg for den taxa betale, jeg for den tolk betale, jeg for den læge betale eller han la mig dø i seng. Jeg den hotelpersonale på hotel snakke med, med de bare sige, de ikke forstå, hvad jeg sige, jeg bare forkølet, de mig banket på ryggen har, de mig te lave. De mig på diskotek invitere. De i den diskolys gramse på White Girl, og den penis trække ud af bukserne på toilet. De gerne kysse død hvid pige, ingen problem. Åh, de synes rigtig dejlig kaste White Girl op på toiletbrædt, hun hænge ud over kant, fuld af feber og krampe i mave, de rigtig kneppe til, så kød på lår gynge frem og tilbage, mens White Girl kaste op på gulv. "Du den drink ha?" de spørge, mens de rigtig tæske White Girl i røv. "Du rigtig liderlig," de sige, "ligesom damer i blad. Ligesom den Lolita og cougar og rødhåret dame med lang pat, der sluge sabel og lille gammel dame, der kneppe puddel og liderlig tøs, der bare elske tæv og pige, der vil bolles med grantræ." (21)

Teksten gengiver White Girls oplevelse af i en svag position at være blevet økonomisk og seksuelt udnyttet, men den opskruede og overdrevne beretning gør også, at man som læser må sætte spørgsmålstegn ved, om White Girls gengivelse er troværdig, eller om hun tværtimod selv har givet frit løb for sine værste fordomme. Og hvem er i så fald mest afstumpet: White Girl eller de andre? Man ledes til at anlægge et dobbeltblik på beretningen, og at der ikke er tale om nogen hverken uskyldsren eller blid, lille hvid pige, fremgår da også af bogen som helhed.

Beretningerne er gennemgående kendetegnet ved, at White Girl ikke accepterer offerrollen, men slår igen med aggressive verbale udfald mod dem, hun har følt sig forulempet af. Mange af teksterne ender i raserianfald og vilde udgydelser af skældsord. Et udpluk af teksternes afsluttende sætninger kan illustrere det: "Du lukke din kæft eller jeg lave den vold på dig, latinomand!" (9), "Hva fuck give dig lov til at dømme min hvide skind?" (12), "Du gemme dig bag den træ eller du får den tæv!" (14), "Du æd din ord; du skamme dig!” (15), "Bøj dig i den støv for den rigdom, du utaknemlig satan!" (22), "Du gå hjem og skamme dig, du den politiskilt putte i den blender!" (23) og "Jeg fucking flå dig og udstoppe dig. Den flæskeskrumpehoved jeg stille på kaminhylde" (37). De mellemmenneskelige relationer fremstår mildest talt konfliktfyldte, og selvom White Girl i udgangspunktet er offeret, vidner hendes reaktioner om, at hun ikke har trukket sig fra den kamp om magt og herredømme, som pågår i teksterne.

I kraft af denne fremstilling af White Girl bidrager Hagen desuden til samtidslitteraturens række af oprørske kvindebilleder. Der synes næsten at være gået mode i alternative kønsrepræsentationer, og hvor man traditionelt forbinder kvinderollen med følelsesfuldhed, ømhed, omsorg, kærlighed og tilbageholdenhed, er det viltre, aggressive og vrede et gennemgående træk ikke kun i forhold til mange af de litterære kvindeskildringer, men også i eksponeringen af de kvindelige forfattere 
selv. Christina Hagen er i sin bog afbilledet med vildt hår og et hårdt, vredt blik, og som reklamebanner for bogen på internettet valgte Gyldendal at eksponere netop dette træk: "Fuck den er vild", lød det med en gengivelse af et citat fra Lilian Munk Rösings anmeldelse i Politiken, der nok kan siges at matche den slagfærdige tale i White Girl, men ikke siger så meget om dens litterære kvalitet. Tilsvarende noterede Weekendavisens Lars Bukdahl i sin anmeldelse, at der til trods for forsidens betegnelse digte, snarere var tale om et raserianfald. ${ }^{\text {Io }}$

Hermed kan vi endnu engang trække en forbindelse til Andkjær Olsen og Moestrup, der ikke kun gentagne gange har beskæftiget sig med mytologiske og sagnomspundne furieagtige kvindeskikkelser i deres tekster, men som også selv er blevet eksponeret som sådanne. Da Bukdahl anmeldte Moestrups $D \emptyset, L \emptyset G N, D \emptyset$, var anmeldelsen akkompagneret af et billede af Medusas afhuggede, slangelokkede hoved og endte med følgende kommentar: "hvis man forestillede sig, at Medusas hårlokker var kuglepenne i stedet for slanger, ville man have et meget præcist billede på, hvordan Mette Moestrups skrift ter sig, når hun rasende står på hovedet: Et farligt, dominerende rod!" (Bukdahl 2012a). Tilsvarende var Bukdahls omtale af Ursula Andkjær Olsens nyeste bog Det 3. årtusindes hjerte (2012) introduceret på forsiden af Weekendavisens Bøger med ordene "Rasende. Ursula Andkjær Olsen er en stilsikker furie med sans for både skønhed og resignation". Ikke alene forfatterindernes litterære skikkelser, men også deres egne personer og skrivepraksis forbindes med oprørske og vrede kvindefigurer. Hertil kan nævnes, at Moestrup og Ravn ved flere lejligheder har optrådt med et hekseshow. De har med andre ord også selv iklædt sig en på én gang farlig, klog, forfulgt og sagnomspunden kvinderolle, og i kreationen af en såkaldt gift/modgift indgik desuden flere elementer fra deres bøger, herunder bl.a. den gennemsigtige glasrevolver fra $D \emptyset, L \emptyset G N, D \emptyset$ og naturligvis: mælk.

\section{Medsøstre - Amalie Smith og Asta Olivia Nordenhof}

I de foregående diskussioner af værker, der tematiserer køn, krop og identitet på såvel et nært, individuelt niveau som i et videre, globalt perspektiv, har vi til stadighed haft blikket vendt mod værkernes formmæssige udtryk. Vi har iagttaget, hvordan destabiliseringen af faste forestillinger om $\mathrm{k} ø \mathrm{n}$, krop og identitet er blevet fulgt af æstetiske normbrud og nydannelser. Det er tydeligt allerede hos Ursula Andkjær Olsen og Mette Moestrup, og opgøret med klassiske forventninger til digtgenren har vi ligeledes set i den efterfølgende generation, hvor Ravns og Hagens genrebetegnelser poesi og digte lægger op til diskussion.

Med Amalie Smiths I civil (2012) og Asta Olivia Nordenhofs Et ansigt til Emily (2011) sættes spørgsmålet om genre i spil fra begyndelsen. Smith kalder sin bog for en "samling", mens Nordenhofs er uden genrebetegnelse. Værkerne placerer sig umiskendeligt inden for den tendens til at nedbryde genreskel, som man har set igennem de seneste år. Konkret indeholder de da også en flerhed af teksttyper. Foruden digte optræder der bl.a. lister, fragmenter, definitioner, refleksioner, dagbogsnotater og fotografier i Smiths bog, der lige så lidt som en traditionel digtsamling er en kortprosasamling, og mest af alt må ses som sin helt egen type samling. For 
Nordenhofs vedkommende drejer det sig om forskellige fortættede skriftstykker i form af bl.a. replikudvekslinger, dagbogsoptegnelser, noter og breve. Ingen af disse tekster kan identificeres som digte i traditionel forstand - hvad Hagens imidlertid heller ikke kunne, selvom de kaldte sig sådan. Dog fremviser de en koncentration i udtrykket, der legitimerer deres placering på grænsen af denne artikels sammenhæng, ligesom opbruddet fra de fikserede former overordnet betyder, at vi også som recipienter skal passe på med at fastholde rigide genreforestillinger.

Når Smith anvender betegnelsen "samling" om sin bog, skal det tages helt konkret. I civil er opbygget som en kollektion af forskellige tekster og fotografier og tematiserer eksplicit dette forhold. Foruden på et metatekstuelt niveau at rejse spørgsmålet om, hvad en samling er, bringes begrebet indholdsmæssigt i spil. Det sker, idet værket beskriver mineralsamlinger og andre former for samlinger af ting, dyr og objekter, og ikke mindst fordi dets hovedforløb handler om et kærlighedsforhold, der er præget først af enhed siden af splittelse. Yderligere afspejles samlingsbegrebet i værkets ydre komposition, hvor der er en ramme i form af en indledende og afsluttende tekst på sort papir, som har angivelsen September. Disse tekster markerer en indgang til samlingen - hvad en samling er, hvad den kan indoptage, og hvad den frastøder, er blandt de spørgsmål, som rejses her - og en udgang fra den, eftersom det sidste afsnit handler om at frigøre sig fra den sammenvoksede tilstand med et andet menneske. Samtidig med at tekstens jeg skriver sig frem mod en position, hvor kærlighedslykkens snævre forening er opløst, antydes det dog, at der er samhørigheder på endnu videre niveauer: Jeget ser sig finalt "som en af mange viljer i et socialt økosystem, påvirkende og påvirket af verden” (94).

Foruden denne ramme består værket af fem afsnit, som skal læses som koncentriske cirkler, der lægger sig uden om hinanden. Det første afsnit, eller kernen i værket, kredser om den omtalte kærlighedshistorie, hvor de elskende på det nærmeste er groet sammen. En af teksterne bærer titlen "Fælleskrop", og en passage derfra lyder: "Vi har hver vores krop, men også en fælles krop i sengen. En udvidet krop, som inkluderer sengen. Og værelset og udsigten. I en historie, vi fortæller, er der en cirkel og inden i den en anden cirkel, og det fortsætter" (13). De elskende befinder sig i en amorf tilstand, hvor det egne og det fremmede, det indre og det ydre flyder sammen. De bliver som børn på ny og kan med Freuds begreb siges at indtræde i en form for før-individuel, oceanisk tilstand, eller de regredierer med Smiths egne ord endnu længere tilbage i en embryon tilstand:

46 Det er, som om vi bliver yngre og yngre, folder os ind i en tvillingefostertilstand, slider huden af hinanden ved bare at kysse og sutte og elske, så hjertet bliver blødt som en klat smør på kroppenes grød - den grød, der kan mætte os begge. (22)

Allerede i det andet afsnit indledes opløsningsprocessen imidlertid. Det mandlige du er blevet ramt af kræft, og i det skildrede sygdomsforløb er det ikke kun hans egen krop, der er under angreb; den fælles krop begynder tillige at falde fra hinanden. Ligesom det var tilfældet med samhørigheden mellem jeget og duet, beskrives sygdoms- og opløsningsprocessen ud fra et konkret kropsligt perspektiv. Smiths værk mikser på original vis poetiske, filosofiske og naturvidenskabelige diskurser, 
og i afsøgningen af sygdommen er der i særlig grad fokus på de forandringer, den afstedkommer på kroppen. Herunder hører vi om kropslige aflejringer i form af kemoterapiens kemiske lugte, hud og hår på lagenet. Selv sorgen forrykkes fra et sjæleligt register, og via en udtræksmetaforisk kombinatorik objektiveres og antropomorficeres den i forskellige former fra en eksotisk frugt til et øje, en kind, et lod, en udposning, en pose og en væske.

I det tredje afsnit bevæger vi os yderligere på afstand af jegets initiale samhørighed med du'et. Vi begiver os ud i et kredsløb, hvor der reflekteres over samlingen som erindringsform, såvel når det handler om mineralsamlinger på museer som på et familiært plan, hvor erindring føjes til erindring og skaber identitet og historie. Også i forhold til disse samlinger oplever vi dog, at de har hver deres tid, og med reference til en historie om jegets bedsteforældre, hvis samling opløstes med deres $\mathrm{d} \varnothing \mathrm{d}$ og rømningen af deres hus, erfarer vi endnu engang den dialektik af samling og opløsning, der går som en understrøm igennem hele bogen. At noget må udskilles og én samling brydes, for at en anden kan opstå, reflekteres ud fra Julia Kristevas begreb om det abjektale, som Smith henviser til i forbindelse med en skildring af barnets subjektsdannelse og dets trang til at samle på afstødt kropsligt materiale som f.eks. de mælketænder, der er rigt fotograferet i bogens midtersektion. Som vi også har set flere gange i det foregående, er der en psykologisk diskurs tilknyttet de kropslige og identitetsmæssige problematikker.

Det fjerde afsnit fortsætter refleksionerne over den enkeltes betydning i forhold til helheden; over det, vi opfatter som del af vores krop, og det, der er fremmed for den, ligesom individet - som jeg også nævnte i indledningen til artiklen - beskrives som et "forbund af celler" (75). Og endnu engang udvides perspektivet: Fra primært at have haft fokus på jeg-du-forholdet og derefter på familiære relationer rækkes der nu ud mod andre arter. Med reference til bier, der agerer, som var de celler i samme krop, og sætter sig i beskyttende lag omkring deres dronning, gives de koncentriske cirkler i bogen endnu et betydningslag. Den stadige forskydning udad - som vi også oplever, når vi kaster en sten på en vandoverflade - virker på flere måder, og i det femte afsnit tager udvidelsesprocessen for alvor fart. Vi bevæger os her op på niveauer, der angår fremtiden, universet, civilisationen og klimakrisen. Samtidig opleves det endelige brud med du'et som en konkret fysisk fornemmelse, "et slags svup" (88), som jeget sanser, idet det tager alene på en ellers fælles planlagt ferie, og flyet letter fra jorden. Sorgfuldheden til trods ender kærlighedshistorien dog ikke dystert. Adskillelsesprocessen udgør også et afsæt for, at jeget kan genvinde sin egen identitet: "Det bliver ikke mørkt: Jeg ser gennem mine egne øje" (ibid.), lyder afsnittes sidste ord.

Når man sammenligner Smiths værk med de foregående, står det klart, at spørgsmålet om køn er veget til fordel for en mere almen afsøgning af kærlighedens væsen i dens såvel samlende som opløsende stadier. Til gengæld befinder kroppen og identiteten sig vedvarende i centrum af værket. Ligesom Ravns poesi overraskede i kraft af sin dissekerende, fysiologiske tilgang til kvinden, udgår Smiths eksistentielle afsøgninger fra et markant materialistisk grundlag. Med sidestykke i Moestrup, som i et afsnit om Cleïs i $D \emptyset, L \emptyset G N, D \emptyset$ fremviser eksempler på ekstrem materialisme ("Jeg er det hårdeste stof i verden. / Min kemiske formel er C. / Ved gnidning bliver jeg 
elektrisk / og kan tiltrække små papirstumper" (75)) repræsenterer Ravn og Smith det materialitetens pres, som Mikkel Krause Frantzen kommenterer i artiklen "Poetisk materialisme". De gør det dog på forskellig vis. Med Franzens ord er materialiteten hos Ravn "massiv, den er klistret og klæbrig, solid og blodig", mens Smith eksponerer en mere luftig og mineralsk materialitet "som på en og samme gang er mere atomar og mere planetarisk" (Frantzen 2012). I relation til Smith og hendes inddragelse af Jane Bennetts udsagn "We are walking, talking minerals" (71), skriver Frantzen uddybende:

4 Det er ikke en metafor. Det er sådan, det er. Bennetts bog hedder i øvrigt Vibrant Matter. Tanken er, at der er en særlig vibration, eller rytme, i værens materialitet. Det er dén vibration, den rytme af samling og opløsning, som er en del af I Civil på et grundlæggende niveau: Sorgen, kræftsygdommen, kærligheden - alle disse 'hovedtemaer' i bogen er at forstå som rytmiske vibrationer. Der er hele tiden en materiel bevægelse mellem samling og opløsning; mennesker og materialer filtres og foldes ind i hinanden, ud af hinanden, indgår i stadigt nye forbindelser. (Frantzen 2012)

Og måske er det denne særlige sitren, som bogen også forplanter til sin læser. Smiths poetiske udtryk rummer ikke som de foregående hverken vrede, ironi, aggression eller provokation. Hun har ikke samme hårdtslående tone, efterstræber ikke på samme - nogle gange lidt anstrengende - måde det originale og overraskende. I civil udtrykker sig derimod på sin egen dybtfølte og eftertænksomme vis og er efter min mening et af de mest vellykkede nye værker.

Som et sidste eksempel på, hvordan krop, køn og identitet er kommet i centrum for poetiske afsøgninger, vil jeg kort inddrage Asta Olivia Nordenhofs Et ansigt til Emily. Bogen er blevet set som en kommentar til Mikkel Thykiers Daglig tale (2002), der ligeledes placerer sig i et genremæssigt udefinerbart felt mellem langdigt, kortroman og teatermonolog. II I Thykiers værk var det imidlertid kun hovedpersonen Frederik, der talte, mens den kvindelige figur Emily forholdt sig tavs og lyttende. Det laver Nordenhof om på, idet hun lader Emily komme til orde. Allerede her aner man, at der er et kønspolitisk spil i gang, og eftersom navnet Emily også associerer til Emily Dickinson, kan dette forhold ses i forbindelse med et endnu videre opgør med den usynliggørelse og tavshed, som i århundreder var kvinders og kvindelige forfatteres lod.

Et ansigt til Emily kredser om de fire figurer Rosa, Emily, Daniel og Rosas far. Hvad mændene angår, er de dog på grænsen til at svinde bort. Rosas far er død og optræder i spøgelsets form; Daniel beskrives som fraværende og uden for tid og rum. Mændenes fysiske realitet er med andre ord problematiseret allerede inden for fiktionen, og samtidig lægger man mærke til, at de som tekstproducenter er trådt i baggrunden: Rosa genskriver sin fars dagbog, og Emily besvarer selv sine breve til Daniel. Hvor det traditionelt var kvinderne, der havde svært ved at komme til tasterne, forholder det sig nu omvendt. Forholdet mellem personerne udgør desuden et komplekst net af kærlighedsrelationer. Rosa elsker Emily, som hun lever sammen med, og som kalder hende sin kone. Emily, der har været gift mange gange før og har et projekt om at skrive med kroppen, elsker Rosa tilbage, men er samtidig forel- 
sket i den udefinerbare Daniel. Kærligheden mellem Rosa og hendes afdøde far er uformindsket og har til tider et næsten incestuøst præg.

Kærlighedsrelationerne løftes ud af deres traditionelle rammer og går på kryds og tværs af levende og døde, virkelige og fiktive, mænd og kvinder, børn og forældre. Labiliteten og åbenheden synes at være et gennemgående træk ved værket, og det er meget svært at komme på det rene med, hvad der foregår. Heller ikke Emily kan reelt fikseres tidsligt og rumligt. Såvel hendes identitet som hendes køn og krop er til stadig forhandling, og i et af sine breve til Daniel skriver hun: "Jeg viger bort fra alle herredømmer, det ved du da om mig" (23). Netop modviljen mod repressive strukturer udvundet af fasttømrede dikotomiske begrebspar er et centralt træk, der binder alle de værker sammen, som denne artikel har fokuseret på. Den Emily, der siges at få et ansigt, forbliver i en ubestemmelig mellemposition for læseren. En position, hvor hun changerer mellem at være til mænd og kvinder, at være skøge og kone, at høre en fortidig og en nutidig verden til, og at være virkelig og uvirkelig.

\section{Arven}

Efter at have været omkring en række af samtidspoesiens markante kvindelige forfattere og have afs $ø$ gt slægtskabet imellem deres værker, er det nu blevet tid til kortfattet at gøre boet op og stille spørgsmålet om, hvilket samlet indtryk deres bøger efterlader sig. Og her tegner der sig ikke blot et klart billede af, at krop, køn og identitet er rykket i centrum for værkerne og danner vigtige felter for poetisk udforskning og refleksion. Det er også tydeligt, at de traditionelle forestillinger om det mandlige og det kvindelige er under ombrydning, og at kroppens og materialitetens betydning betones frem for sjælelige registre, ligesom der er en tendens til nedbrydning af genrer og herunder en radikal eksperimenteren med poesiens udtryksformer og grænser. De unge forfatterinder synes med andre ord at trives i et oprørsk hjørne, hvor ellers så fasttømrede dikotomier bryder sammen, og der gøres op med overleverede forestillinger om og forventninger til kvinder og poesi. De skriver poesi med et subversivt potentiale.

\section{Noter}

I Se Guldager 2012.

2 Se Nexø 2011, Frantzen 2011 og Friis 2012.

3 I min gengivelse af citater fra "Navnløs" skelner jeg mellem store og små bogstaver, mens tekstens brug af forskellige skrifttyper og fed ikke er gengivet.

4 I artiklen "Den forbandede krop" udlægger Elisabeth Friis ammesporet på følgende vis: "Her anvendes den hellige, almindelige amme-erfaring og den traditionelle metafor »at nære en slange ved sin barm» (»Du er sugende for FANDEN. Du er sugende«) som katalysator for en voldsom kritik af, at samfundets bipolære tankestrukturer (dem og os, det gode og det onde) også invaderer den biologiske krop. For eksempel som forestillingen om, at der findes et Good Breast og et Bad Breast, hvilket desværre er en ret almindelig måde at betragte sine mælkefyldte bryster på” (Friis 2012). 
det billede, som den litterære tradition tilbyder kvinder, netop er polariseret imellem "englen og uhyret, mellem den søde, tavse snehvide og den gale, rasende dronning" (Gilbert 2012, 160), og de diskuterer den betydning, det har for kvinders vej til forfattergerningen.

6 Hvor jeg i min artikel "Samtidslyrikkens tværmediale liv. Et rids over en genre i forandring" (2012) noterede, at Gyldendal - ligesom mange andre store forlag - op igennem nullerne kom til at spille en mindre rolle for eksponeringen af unge forfattere og ny eksperimenterende litteratur, har man inden for det seneste år kunnet se tegn på, at forlaget igen er begyndt at markere sig stærkere på dette punkt. Det gælder således ikke kun for Ravn og Hagen, at de er udkommet på Gyldendal i 2012, men også f.eks. Amalie Smith og Julie Sten-Knudsen. Det var ligeledes Gyldendal, der i 2011 udgav Bjørn Rasmussens Huden er det elastiske hylster der omgiver hele legemet, som såvel formelt som i sine skildringer af krop og erotik er et af de mest grænseoverskridende nyere prosaværker.

7 I forordet til bogen Feminisme påpeger Lilian Munk Rösing og Tania Ørum tilsvarende, at Julia Kristeva i La Révolution du langage poétique (1974) ser litteraturens revolutionerende effekt ikke så meget $\mathrm{i}$ indholdet som $\mathrm{i}$ "den eksperimentelle skrivemåde, der splintrer sprogets symbolske orden og dermed kaster læseren tilbage på de grundlæggende spørgsmål om identitet, andethed, kroppens natur og kønnets konstruktion" (Rösing 2012, 16). Altså på de selvsamme spørgsmål, som står så centralt i ny dansk poesi.

8 Se f.eks. Anne Vindums fine portræt af Olga Ravn på Forfatterweb (Vindum 2012). Gertrude Stein hører i det hele taget til blandt de avantgardeforfattere, som i en dansk sammenhæng nykanoniseres omkring årtusindskiftet, og som bliver en vigtig inspirationskilde for mange af de yngre digtere, herunder også Ursula Andkjær Olsen, Mette Moestrup og Niels Frank (Larsen 2009: 231ff.). Den store interesse for Steins forfatterskab har foruden oversættelser af hendes værker også ført til etableringen af Steinselskabet i 2006.

9 Netop dette citat har Ravn omtalt som et af sine favoritcitater, se Guldager 2010.

Io Se Bukdahl 2012b.

II Se Zangenberg 2011.

\section{Litteratur}

Bukdahl, Lars (2012a): "Medusa var beautiful”, i Weekendavisen 08.06.2012.

Bukdahl, Lars (2012b): "Du rigtig smile falsk til mig”, i Weekendavisen 15.06.2012.

Butler, Judith (1993): "Passing og queering. Nella Larsens psykoanalytiske udfordring", i Lilian Munk Rösing og Tania Ørum (red.): Feminisme (2012), Aarhus: Aarhus Universitetsforlag.

Frantzen, Mikkel Krause (2011): "Ungdomssind”, i Information 22.12.2011.

Frantzen, Mikkel Krause (2012): "Poetisk materialisme”, i Information 31.05.12.

Friis, Elisabeth (2012): “Den forbandede krop”, i Information 02.02.2012.

Gilbert, Sandra M. og Susan Gubar (2012): “Smitte i sætningen. Den kvindelige forfatter og angsten for forfatterskab”, i Lilian Munk Rösing og Tania Ørum (red.): Feminisme (2012), Aarhus: Aarhus Universitetsforlag.

Guldager, Louise Helstrup (2010): “Tidens trodsige tøser”, i Information 10.11.2010.

Hagen, Christina (2012): White Girl, København: Gyldendal.

Klein, Melanie (1988): "A contribution to the psycogenesis of manic-depressive states" (1935), i Love, Guilt and reparation and other Works 1921-1945, London: Virago Press.

Langås, Unni (2009): “Kjønnets materialitet eller materialitetens kjønn? En diskussion af Ju- 
dith Butlers Bodies that Matter". Se http://kilden.forskningsradet.no/c35640/artikkel/vis. html?tid=57523\&strukt_tid $=35640$.

Larsen, Peter Stein (2009): Drømme og dialoger. To poetiske traditioner omkring 2000, Odense: Syddansk Universitetsforlag.

Larsen, Peter Stein (2012): "Med feriepostkort som inspiration”, i Kristeligt Dagblad 14.07.2012.

Moestrup, Mette (2012): $D \emptyset, L \emptyset G N, D \emptyset$, København: Gyldendal.

Mønster, Louise (2012): "Samtidslyrikkens tværmediale liv. Et rids over en genre i forandring", i Kritik 203.

Nexø, Tue Andersen Nexø (2011): “Endnu et kinderæg til samlingen”, i Information 17.11.2011.

Nordenhof, Asta Olivia (2011): Et ansigt til Emily, København: Basilisk.

Olsen, Ursula Andkjær (2010): Have og helvede, København: Gyldendal.

Ravn, Olga (2012): Jeg æder mig selv som lyng, København: Gyldendal.

Rösing, Lilian Munk og Tania Ørum (red.): Feminisme (2012), Aarhus: Aarhus Universitetsforlag. Smith, Amalie (2012): I civil, København: Gyldendal.

Stein, Gertrude (2004): Ømme dupper. Oversat af Peter Laugesen efter Tender Buttons (1914), København: Borgen.

Sten-Knudsen, Julie (2011): Hjem er en retning, København: Gyldendal.

Serup, Martin Glaz (2010): Marken, Aarhus: After Hand.

Tindbæk, Birgitte (2012): "Kroppen i litteraturen - august 2012". Se http://www.litteratursiden. $\mathrm{dk} /$ temaer/kroppen-i-litteraturen-august-2012.

Vindum, Anne (2012): “Olga Ravn”. Se http://www.forfatterweb.dk/oversigt/ravn-olga/hele-portraettet-om-olga-ravn.

Zangenberg, Mikkel Bruun: "Debutant begår forrygende og finurlig kærlighedsroman”, i Politiken 22.11.2011.

Ørntoft, Theis (2009): Yeahsuiten, København: Gyldendal. 